\title{
A MAGASFELHARMONIKUS-KELTÉS KVANTUMOPTIKAI VONATKOZÁSAI
}

\author{
Gombkötő Ákos ${ }^{1}$, Varró Sándor ${ }^{2,3}$, Keresztes Zoltán ${ }^{1}$, Gábor Bence ${ }^{1}$, Földi Péter ${ }^{1,2}$ \\ ${ }^{1}$ Szegedi Tudományegyetem, Elméleti Fizikai Tanszék, Tisza L. krt. 84-86, 6720 Szeged \\ ${ }^{2}$ ELI-ALPS, ELI-HU Non-Profit Kft., Wolfgang Sandner utca 3, 6728 Szeged \\ ${ }^{3}$ Wigner Fizikai Kutatóközpont, Konkoly-Thege M. út 29-33, 1121 Budapest
}

DOI: https://doi.org/10.14232/kvantumelektronika.9.12

\section{Bevezetés}

Nagyintenzitású elektromágneses terek esetén a magas fotonszám miatt nem szokás a mező kvantált, azaz a fotonképet alkalmazó leírását alkalmazni. Ugyanakkor a magasfelharmonikus-keltés folyamata során a jelenség alacsony hatékonysága miatt a felharmonikusok a gerjesztésnél már sokkal kisebb intenzitásúak, így ilyenkor még a szokásos ökölszabály szerint is hasznos a felharmonikus módusok kvantumoptikai leírása. Emellett, érdekes módon, kísérleti eredmények utalnak arra, hogy maga az erös gerjesztő tér is rendelkezik olyan tulajdonságokkal, amelyek csak ilyen módon értelmezhetők $[1,2]$. Lényegében arról van szó, hogy az anyagi rendszerrel történő kölcsönhatás után a gerjesztő tér és a felharmonikusok együttes fotonszámeloszlásában a felharmonikus spektrumra emlékeztető struktúra fedezhető fel. Ez a tapasztalat mutatja, hogy még ebben az intenzitástartományában is vannak olyan effektusok, amelyek a kölcsönhatás teljesen kvantumos leírását igénylik.

Erős terekkel kapcsolatban - néhány fontos korai eredménytől [3,4] eltekintve - az elméleti leírás eléggé hiányos, jelenleg is folyó kutatásaink ezt a hiányt igyekeznek betölteni

\section{Modell}

A magasfelharmonikus-keltés folyamatának leírásához három fizikai rendszert kell jellemeznünk: a tipikusan az infravörös tartományba eső gerjesztést, a vele kölcsönható anyagi rendszert, illetve a másodlagos sugárzást, ami az UV frekvenciákig elérő felharmonikusokat is tartalmazza. Ez azt jelenti, hogy a teljes rendszert a következő Hamilton-operátor írja le:

$$
H=H_{e}+H_{m}+H_{H H}+V_{e-m}+V_{H H-m}
$$

ahol az egyes tagok a gerjesztést (excitation), az anyagi rendszert (matter), a felharmonikusokat (HH: high-order harmonics), a gerjesztés és az anyagi rendszer kölcsönhatását, valamint a felharmonikusok és az anyag kölcsönhatását jelentik (ebben a sorrendben). Kvantumos leírás esetében a szabad tereket leíró $H_{e}$ és $H_{H H}$ Hamilton-operátorok $H_{\text {field }}=\sum \hbar \omega_{n}\left(a_{n}^{+} a_{n}+1 / 2\right)$ alakúak, ahol a szumma a figyelembe vett módusokon fut végig. Ez elvben az összes populált módust jelenti, de a modell (esetlegesen numerikus) megoldhatósága érdekében elképzelhető, hogy csak kevesebb módust tudunk figyelembe venni. A kvalitatív kép szempontjából pl. a gerjesztést elegendő olyan monokromatikus sugárzásnak tekinteni, ahol az összeg egyetlen tagot tartalmaz. A kölcsönhatási operátorok $\left(V_{e-m}\right.$ és $\left.V_{H H-m}\right)$ esetén dipólközelítést alkalmazunk. Hosszmértékben $V=-\boldsymbol{D E}$ formába írható, ahol $\boldsymbol{D}$ az anyagi rendszer dipólmomentumának megfelelö operátor, $\boldsymbol{E}$ pedig az elektromos tér. Ez utóbbi nem feltétlenül szükséges, hogy maga is operátor legyen, erős gerjesztés esetén tekinthetjük klasszikus időfüggő mezőnek. Ez azért érdekes, mert jelenleg még erősen leegyszerüsített modellek esetén is igen összetett probléma a teljesen kvantumos leírás kezelése. A 
továbbiakban azokat az eredményeinket ismertetjük, amelyek a kölcsönhatásban résztvevő három rendszer közül kettőnek a kvantumos leírásából adódnak.

\section{Kvantált felharmonikusok, kétállapotú atom és klasszikus gerjesztés}

Első modellünkben [5,6] a felharmonikusokat kvantumosan írjuk le, a gerjesztés pedig klasszikus, azaz $H_{e}$ hiányzik az (1) egyenletből, továbbá

$$
\begin{gathered}
V_{e-m}=-\boldsymbol{D} \boldsymbol{E}_{\boldsymbol{e}}=f(t) \cos (\omega t)\left(\sigma_{x} E_{0}\right) \\
H_{m}=\hbar \omega_{0} \sigma_{z}
\end{gathered}
$$

ahol a kétnívós közelítésnek megfelelően a Pauli-mátrixok jelennek meg, az $f(t)$ burkolófüggvény pedig lassan változik a $T=2 \pi / \omega$ periódusidőhöz képest. Eredményeink alapján ekkor egy adott felharmonikus jelenléte vagy hiánya alig észrevehetően befolyásolja a többi dinamikáját, azaz a HH módusok lényegében függetlenek. Így minden egyes ilyen módus időfejlődését jó közelítéssel kiszámíthatjuk, ha azt a Hamilton-operátort tekintjük, amelyben $H_{H H}$ pusztán az adott módust tartalmazza. Ezen a módon több ezer frekvencia esetén is meghatározhatjuk a dinamikát, beleértve azokat is, amelyek nem egész számú többszörösei $\omega$-nak. Így kaptuk az 1. ábrát.

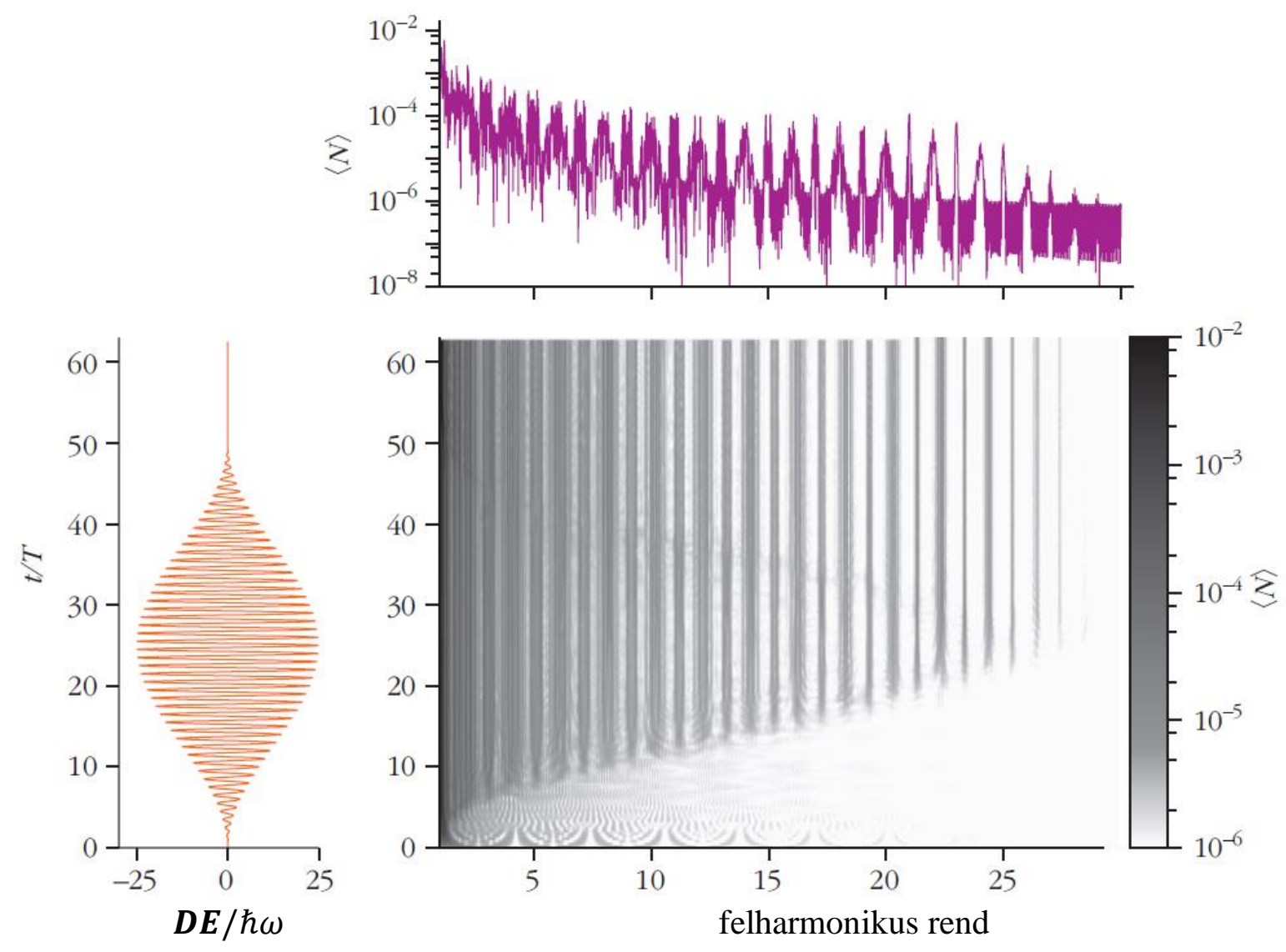

1. ábra: A központi panelen a fotonszámok várható értéke látható az $\omega$ egységekben mért frekvencia és az idő függvényében $(T=2 \pi / \omega)$. Bal oldalon a gerjesztő impulzus térerősségének időfüggése látható dimenziótlan egységekben. A felső ábra a fotonszámok gerjesztés utáni várható értékét mutatja [6]. 
Ezen az ábrán látszik, hogy a kezdetben nulla fotonszám várható értékkel jellemzett módusok hogyan populálódnak az idő előrehaladtával, és hogyan alakul ki a HHG spektrum. A jól ismert kísérleti eredményekkel kvalitatív egyezésben azt kapjuk, hogy $\omega$ egész számú többszöröseihez közel jelennek meg észrevehető maximumok a fotonszám várható értékekben, látható egy „plató” a spektrumban, illetve a harmonikus csúcsok egy idő után eltünnek („,levágás”). Mindez azt mutatja, hogy már a lehető legegyszerübb anyagi modell (a kétállapotú atom) is alkalmas arra, hogy a magasfelharmonikus-keltés folyamatáról kvalitatívan helyes képet adjon. Emellett az is látható, hogy a spektrum szerkezetében kvalitatív különbség van a páratlan és páros felharmonikusok között, ezt a szerkezetet a modell közelítésein belül analitikusan meg tudjuk magyarázni. A felharmonikusokra vonatkozó független-módus közelítésen belül feltérképeztük a magas felharmonikusok koherencia tulajdonságait is [5], megmutattuk, hogy több nemklasszikus tulajdonság (préseltség, szub-poissoni fotonstatisztika) jelen van a felharmonikus sugárzásban, jellemzően a páros felharmonikusok esetén. Általában ezek a jellemzők az egyatomos anyagi rendszer esetében kevéssé térnek el a klasszikus határesettől. Ugyanakkor a fotonszám-keresztkorreláció vizsgálata közben jelentős antikorrelációt sikerült kimutatni a páros-páratlan felharmonikusok között.

Előzetes eredményeink szerint az egyatomos spektrum szerkezete lényegében megegyezik az $N$ darab koherensen gerjesztett kétszintes atom (Dicke-modell) kollektív sugárzási spektrumával.

\section{Kvantált gerjesztés és kétállapotú atom}

Az előző fejezet eredményei mutatják, hogy a felharmonikus módusok jelenléte - fizikailag a keltési folyamat alacsony hatékonysága miatt - nem befolyásolja számottevően az anyagi rendszer és a gerjesztő módus csatolt dinamikáját. Mivel a kísérleti eredmények a kölcsönhatás után a gerjesztés fotonstatisztikájára, a „hiányzó fotonokra” vonatkoznak [1,2], érdemes a gerjesztést kvantumosan kezelni, miközben a fentiek alapján (és a számítások megkönnyítése érdekében) a felharmonikusok jelenlétét elhanyagoljuk [7,8]. Ha a gerjesztő módus kezdetben koherens állapotban van, akkor a dinamika folyamán ez az állapot több, szintén koherens részre esik szét. Kicsit részletesebben, arról van szó, hogy a kölcsönhatás során kvantumos összefonódottság épül fel a gerjesztő módus állapota és a kölcsönhatást leíró dipólmomentum operátor sajátállapotai között. Az összefonódott állapot egyes tagjaihoz különböző dinamika tartozik, más utakat járnak be a fázistéren. A lenti ábra a kétállapotú atom esetére (amikor $D_{x}=\sigma_{x}$, összesen két sajátállapottal) mutatja ezt a jelenséget a Wigner-függvény segítségével.

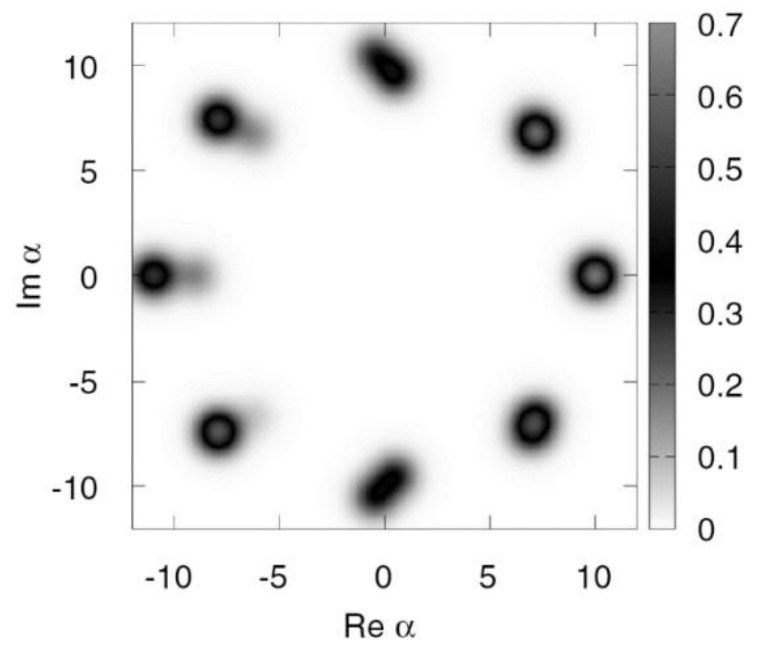

2. ábra: A gerjesztő módus Wigner-függvényének időfejlődése. A nyolc, jól elkülöníthető rész különböző időpillanatokhoz tartozik az első optikai ciklusban: $\mathrm{t}=0 ; \mathrm{t}=1 / 8 \mathrm{~T} ; \mathrm{t}=2 / 8 \mathrm{~T}, \ldots, \mathrm{t}=7 / 8 \mathrm{~T}$. A módus kezdőállapota egy $\alpha=10$ indexü koherens állapot, míg az atom $t=0$-ban alapállapotban van. A kölcsönhatás erősségét jellemző Rabi-frekvencia az atomi rezonanciafrekvencia fele, a gerjesztés pedig távol van a rezonanciától: $\omega / \omega_{0}=3[8]$. 
A folyamat során - nagyon jó közelítéssel - az történik, hogy az anyagot leíró Hamilton operátor gyors átmeneteket indukál az összefonódott állapot részei között, és ezek az átmenetek azok, amelyek a felharmonikusok létrejöttéért felelősek. Másszóval ahhoz, hogy a felharmonikusok megjelenjenek, mindenképpen szükség van a szabad anyagi rendszert leíró $H_{m}$ operátorra is.

\section{Kvantált gerjesztés és kvantált felharmonikusok}

Az (1) egyenletben nem szerepel közvetlen kölcsönhatás a gerjesztés és a HH módusok között. Az anyagi rendszer az, ami csatolást hoz létre az elektromágneses terek között. Ezt a legtisztábban úgy tanulmányozhatjuk, ha bevezetünk egy olyan Hamilton-operátort, amelyben az anyag csak magasrendủ szuszceptibilitás jellegű paramétereken keresztül jelenik meg:

$$
H_{g-H H}=H_{g}+H_{H H}+\sum_{m} \chi^{(m)}\left[a_{g}^{m} a_{m}^{\dagger}+\left(a_{g}^{\dagger}\right)^{m} a_{m}\right]
$$

ahol a keltő és eltüntető operátorok $g$ indexe a gerjesztésre vonatkozik, $m$ pedig azt a HH módust jelenti, amely frekvenciája a gerjesztésének az $m$-szerese: $\omega_{m}=m \omega$. Hasonló Hamilton-operátort egyetlen taggal a szummában $(m=2)$ a másodharmonikus-keltés, illetve a vele ellentétes folyamat, a parametrikus lekonverzió leírására szokás használni [9]. A (2) Hamilton-operátor által generált dinamika esetén könnyen tudunk az egyes módusok fotonszámaiból megmaradó mennyiséget

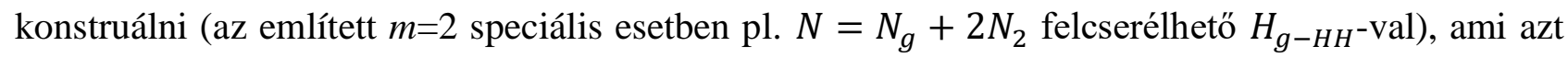
mutatja, hogy ezzel a módszerrel valóban pusztán a felharmonikus-keltés jelenségére tudunk koncentrálni. A részletek természetesen a $\chi^{(m)}$ mennyiségek egymáshoz viszonyított nagyságában és relatív fázisaikban rejlenek. Az utóbbiakról - a teljes dinamika megoldása, majd pusztán a módusok állapotterére történő redukálása nélkül - keveset mondhatunk. Ugyanakkor, mivel a tipikus harmonikus spektrumok ismertek, a magasrendủ szuszceptibilitások abszolút értékeit megválaszthatjuk úgy, hogy számításaink visszaadják ezeknek a spektrumoknak az 1. ábra felső részén is látható tulajdonságait. Előzetes eredményeink szerint, pusztán néhány módus figyelembe vételével is igen érdekes, strukturált fotonszám-eloszlásokat kaphatunk. Erre mutat példát a 3. ábra.

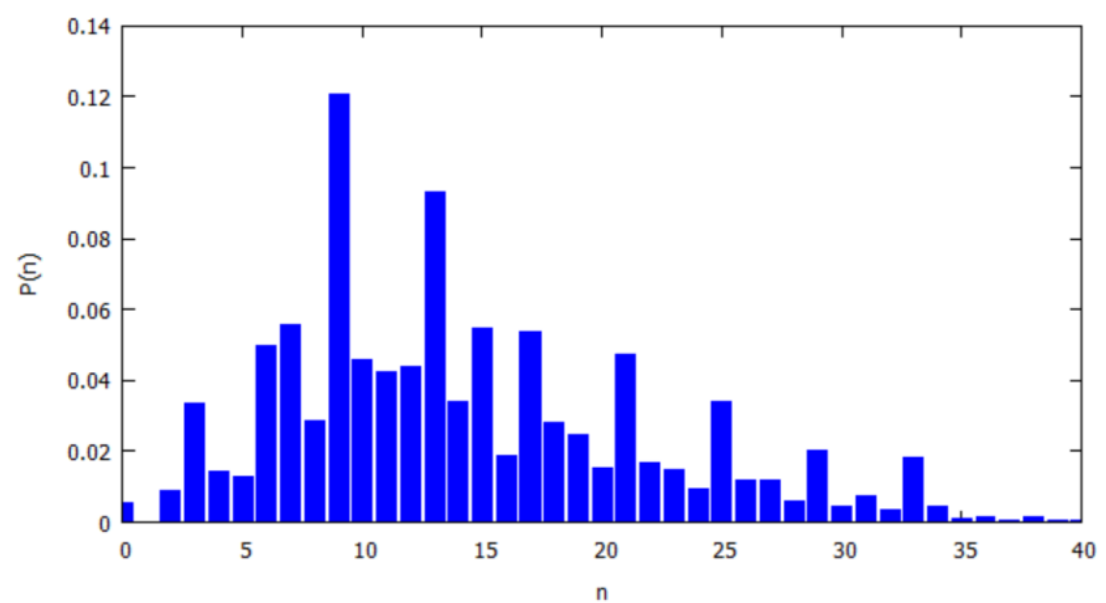

3. ábra: A (2) Hamilton-operátor által generált dinamika 2,5 optikai ciklus utáni eredménye az $\mathrm{m}=2,3,4$ és 5 HH módusok figyelembe vételével. Az ábrán a négy HH módus együttes fotonszámeloszlását láthatjuk. $\mathrm{A} \chi^{(2)}, \chi^{(3)}, \chi^{(4)}$ és $\chi^{(5)}$ mennyiségek valósak, nagyságukat úgy választottuk meg, hogy a kísérleti spektrumokban megjelenő ,„platónak” megfelelően a fotonszámok várható értéke azonos legyen ezekben a módusokban. 
A (2) egyenlet után említett fotonszám megmaradási tulajdonság azt is jelenti, hogy a fenti ábra struktúrája megjelenik a gerjesztésből „hiányzó” fotonok eloszlásában is, ami a kísérletekkel közvetlenül összehasonlítható eredmény.

\section{6. Összefoglalás}

A fentiekben azt a munkát foglaltuk össze, amelyet a magasfelharmonikus-keltés kvantumoptikai leírása kapcsán végeztünk [5-8]. Megmutattuk, hogy a folyamatban résztvevő gerjesztés, anyagi rendszer és a másodlagos sugárzás hármasából bármelyik kettőt kvantáltan kezelve érdekes eredmények adódnak. Ennek fényében további munkánk célja a teljes folyamat kvantumos leírása.

\section{Köszönetnyilvánítás}

A projekt az Európai Unió támogatásával, az Európai Szociális Alap társfinanszírozásával valósul meg. EFOP-3.6.2-16-2017-00005-Ultragyors fizikai folyamatok atomokban, molekulákban, nanoszerkezetekben és biológiai rendszerekben.

Munkánkat támogatták továbbá TUDFO/47138-1/2019-ITM FIKP és a GINOP-2.3.2-

15-2016-00036 számú pályázatok. Magát az ELI-ALPS projektet (GINOP-2.3.6-15-2015-00001) az Európai Unió és az Európai Regionális Fejlesztési Alap támogatja.

\section{Irodalom}

[1] N. Tsatrafyllis, I. K. Kominis, I. A. Gonoskov, P. Tzallas, Nat. Comm. 8, 15170 (2017). https://doi.org/10.1038/ncomms15170

[2] N. Tsatrafyllis, S. Kühn, M. Dumergue, P. Földi, S. Kahaly, E. Cormier, I. A. Gonoskov, B. Kiss, K. Varjú, S. Varró, P. Tzallas, Phys. Rev. Lett. 122, 193602 (2019). https://doi.org/10.1103/PhysRevLett.122.193602

[3] J. Bergou, S. Varró, J. Phys. A: Math. Gen. 14, 1469 (1981). https://doi.org/10.1088/0305-4470/14/6/023

[4] J. Bergou, S. Varró, J. Phys. A: Math. Gen. 14, 2281 (1981). https://doi.org/10.1088/0305-4470/14/9/023

[5] A. Gombkötő, A. Czirják, S. Varró, P. Földi, Phys. Rev. A 94, 013853 (2016). https://doi.org/10.1103/PhysRevA.94.013853

[6] P. Földi, Fizikai Szemle 67, 345 (2017).

[7] Á. Gombkötő, S. Varró, P. Mati, P. Földi, Phys. Rev. A 101, 013418 (2020). https://doi.org/10.1103/PhysRevA.101.013418

[8] Á. Gombkötő, S. Varró, P. Mati, P. Földi, Fizikai Szemle 70, 163 (2020).

[9] T. Toyoda and K. Wildermuth, Phys. Rev. D 22, 2391 (1980). https://doi.org/10.1103/PhysRevD.22.2391

[10] P. Meystre, M. Sargent III, Elements of Quantum Optics (Springer, 2007.) https://doi.org/10.1007/978-3-540-74211-1 